University of Nebraska - Lincoln

DigitalCommons@University of Nebraska - Lincoln

Conference Presentations and White Papers:

Biological Systems Engineering

Biological Systems Engineering

1992

\title{
Darcy-Weisbach Roughness Coefficients for Gravel and Cobble Surfaces
}

John E. Gilley

john.gilley@ars.usda.gov

Eugene R. Kottwitz

Gary A. Wieman

Follow this and additional works at: https://digitalcommons.unl.edu/biosysengpres

Part of the Biological Engineering Commons

Gilley, John E.; Kottwitz, Eugene R.; and Wieman, Gary A., "Darcy-Weisbach Roughness Coefficients for Gravel and Cobble Surfaces" (1992). Conference Presentations and White Papers: Biological Systems Engineering. 41.

https://digitalcommons.unl.edu/biosysengpres/41

This Article is brought to you for free and open access by the Biological Systems Engineering at DigitalCommons@University of Nebraska - Lincoln. It has been accepted for inclusion in Conference Presentations and White Papers: Biological Systems Engineering by an authorized administrator of DigitalCommons@University of Nebraska - Lincoln. 
Published in: HYDRAULIC ENGINEERING: SAVING A THREATENED RESOURCE-IN SEARCH OF SOLUTIONS:

Proceedings of the Hydraulic Engineering Sessions at

Water Forum '92, Baltimore, MD August 2-6, 1992.

Published by American Society of Civil Engineers.

\title{
Darcy-Weisbach Roughness Coefficients for Gravel and Cobble Surfaces
}

\author{
By John E. Gilley, 1 Eugene R. Kottwitz, ${ }^{2}$ and Gary A. Wieman 2
}

\begin{abstract}
A laboratory study is conducted to measure Darcy-Weisbach roughness coefficients for selected gravel and cobble materials. Varying rates of flow are introduced into a flume in which a given size class of gravel or cobble material is securely attached. Roughness coefficients are calculated from measurements of discharge rate and flow velocity. The laboratory data are used to develop regression equations for relating roughness coefficients to surface cover and Reynolds number. Accurate prediction of roughness coefficients for gravel and cobble surfaces will improve our ability to understand and properly model upland flow hydraulics.
\end{abstract}

\section{INTRODUCTION}

Calculation of time of concentration, determination of flow velocity, and simulation of runoff hydrographs require the use of roughness coefficients. Resistance to flow on upland areas may be influenced by soil microrelief, standing vegetative material, residue cover, surface rocks, raindrop impact, and other factors. Roughness coefficients caused by each of these components contribute to total hydraulic resistance.

A description of previous studies involving roughness coefficients on agricultural areas was provided by Engman (1986).

Hydraulic roughness coefficients were developed from runoff plot data originally collected for erosion studies. Friction factors were

1 Agric. Engr., U.S. Dept. of Agric.-Agric. Res. Service, 251 Chase Hall, University of Nebraska, Lincoln, NE 68583-0729.

2 Res. Engr., Dept. of Biological Systems Engrg., 248 Chase Hall, Univ. of Nebraska, Lincoln, NE 68583-0729. 
presented in a tabular format with a description of various surfaces and land uses.

Hydraulic characteristics of rills were measured by Gilley et al. (1990) on several sites located throughout the United States. Regression equations were developed that related roughness coefficients to Reynolds number. A laboratory study was also performed by Gilley et al. (1991) to measure roughness coefficients for selected residue materials. The laboratory data were used to develop regression equations for relating roughness coefficients to residue cover and Reynolds number. The objective of this investigation was to develop regression equations for estimating DarcyWeisbach roughness coefficients for gravel and cobble surfaces.

\section{HYDRAULIC EgUATIONS}

The Darcy-Weisbach equation has been widely used to describe flow characteristics. Under uniform flow conditions, the Darcy-Weisbach roughness coefficient, $f$, is given as

$$
f=\frac{8 g R S}{V^{2}}
$$

where $g=$ acceleration due to gravity; $S=$ average slope; $V=$ flow velocity; and $R=$ hydraulic radius, defined as

$$
R=\frac{A}{P}
$$

where $A=$ cross-sectional flow area; and $P=$ wetted perimeter. For a rectangular flume with flow width $w$

$$
R=\frac{w y}{w+2 y}
$$

where $y=$ flow depth. For overland flow conditions where flow width is much greater than flow depth, hydraulic radius can be assumed to be approximately equal to flow depth.

The Reynolds number, $R n$, is also used to describe flow characteristics, and is given as

$$
R n=\frac{V R}{v}
$$

where $v=$ kinematic viscosity. Kinematic viscosity can be determined directly from water temperature. 
The continuity equation for flow is defined as

$Q=V A$

where $Q=$ flow rate. For a rectangular flume, water depth is given as

$y=\frac{Q}{V w}$

In this study, water depth was determined indirectly using (6) and measurements of $Q, V$, and $w$.

\section{EXPERMMENTAL PROCEDURES}

The size classes of gravel and cobble materials used in this study are shown in Table 1 . Gravel and cobble materials were glued in a random orientation onto a section of reinforced fiberglass sheeting located within the flume. The percentage of surface cover was measured using a photographic grid procedure (Laflen et al. 1978).

The 0.91-m-wide, 7.31-m-long and 0.279-m-deep flume was maintained at a slope of $1.35 \%$. Water was supplied to the flume using a constant head tank. Two replicate tests were run at 10 flow rates. Flow rate was determined immediately before and after each test to ensure steady state conditions. Water temperature was measured following flow rate determinations.

TABLE 1. Regression Equations Relating Darcy-Weisbach Roughness Coefficients to Percent Cover and Reynolds Number for Selected Sire Classes

\begin{tabular}{|c|c|c|c|c|}
\hline \multirow[b]{2}{*}{$\begin{array}{l}\text { Diameter, } \\
\text { (cm) } \\
\text { (1) }\end{array}$} & \multicolumn{3}{|c|}{ Regression Coefficient ${ }^{a}$} & \multirow{2}{*}{\begin{tabular}{|c|} 
Coefficient of \\
determination, \\
$r^{2}$ \\
$(5)$ \\
\end{tabular}} \\
\hline & $\begin{array}{c}a \\
(2) \\
\end{array}$ & $\begin{array}{c}b \\
(3)\end{array}$ & $\begin{array}{l}c \\
\text { (4) }\end{array}$ & \\
\hline $0.25-1.27$ & $1.68 \times 10^{1}$ & $5.78 \times 10^{-1}$ & $7.09 \times 10^{-1}$ & 0.985 \\
\hline $1.27-2.54$ & $1.18 \times 10^{1}$ & $6.78 \times 10^{-1}$ & $6.67 \times 10^{-1}$ & 0.9 \\
\hline $2.54-3.81$ & 1.91 & 1.19 & $6.28 \times 10^{-1}$ & 0.943 \\
\hline $3.81-12.70$ & $1.11 \times 10^{-1}$ & 1.61 & $4.68 \times 10^{-1}$ & 0.944 \\
\hline $2.70-25.40$ & $1.25 \times 10^{-5}$ & 1.63 & $5.68 \times 10^{-1}$ & 0.944 \\
\hline $0.25-12.70^{b}$ & 2.16 & $9.53 \times 10^{-1}$ & $5.50 \times 10^{-1}$ & 0.672 \\
\hline
\end{tabular}

${ }^{a}$ Regression coefficients $a, b$, and $c$ are used in: $f=a$ (percent cover) $b / R n^{c}$

${ }^{b}$ Data for gravel and cobble materials having a diameter range of 0.25

$-12.70 \mathrm{~cm}$ were combined to obtain a generalized regression equation. 
Once steady-state runoff conditions had become established, line sources of fluorescent dye were injected across the flume at downslope distances of 0.91 and $7.01 \mathrm{~m}$. A fluorometer and a stopwatch were used to determine elapsed travel time between the two dye concentration peaks. Mean flow velocity was calculated by dividing the distance between the two line sources of dye $(6.10 \mathrm{~m})$ by the difference in travel time between the two dye concentration peaks. For each test condition, three measurements of flow velocity were made.

\section{RESULTS}

Darcy-Weisbach roughness coefficients at varying Reynolds numbers for gravel material with a diameter of 2.54 to $3.81 \mathrm{~cm}$ are shown in Fig. 1. The trends presented in Fig. 1 are characteristic of gravel and cobble materials having diameters ranging from 0.25 to $12.70 \mathrm{~cm}$.

For the experimental runs shown in Fig. 1 with surface covers of $56 \%$ and $80 \%$, water depth was usually greater than the height of the gravel material. As a result, Darcy-Weisbach roughness coefficients consistently decreased as the Reynolds number became larger. In contrast, water depths at lower Reynolds numbers for the test runs with surface cover values of $4 \%, 16 \%$, and $32 \%$ were typically less than the height of the gravel material. As a result, roughness coefficients initially increased with the Reynolds number. Once flow depth exceeded roughness element height, roughness coefficients became smaller as the Reynolds number increased.

Water depths were usually smaller than the height of the roughness elements for the cobble material having a diameter of 12.70-25.40 cm. As a result, Darcy-Weisbach roughness coefficients generally increased with the Reynolds number (Fig. 2). However, the surfaces with $61 \%$ and $83 \%$ cover showed a substantial reduction in roughness coefficient values at the highest Reynolds number. For this hydraulic condition, flow depth exceeded the height of many of the roughness elements.

Regression equations that relate Darcy-Weisbach roughness coefficients to percent cover and Reynolds number are shown in Table 1. Regression relations are presented for the five selected size classes. In addition, data for gravel and cobble materials having a diameter range of $0.25-12.70 \mathrm{~cm}$ were combined to obtain a generalized regression equation.

\section{SUMMARY AND CONCLUSIONS}

Hydraulic roughness coefficients are required to analyze surface runoff on upland areas. Total hydraulic resistance on a site is usually caused by several factors. Roughness coefficients for gravel and cobble materials were examined in this investigation. 


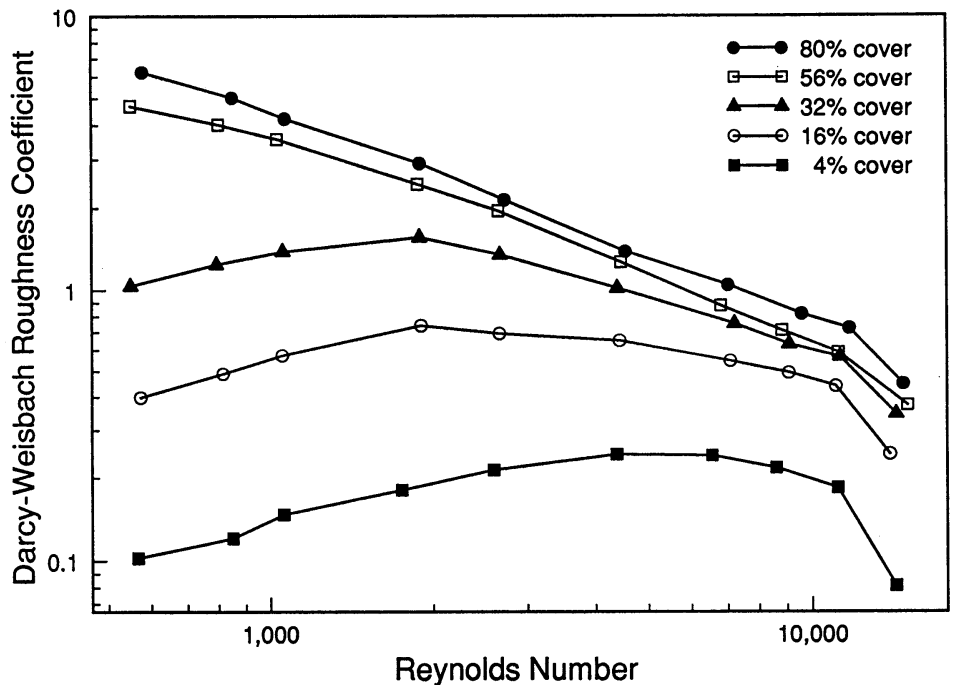

Figure 1. Darcy-Weisbach Roughness Coefficients versus Reynolds Number for Gravel Material with 2.54-3.81-cm Diameter

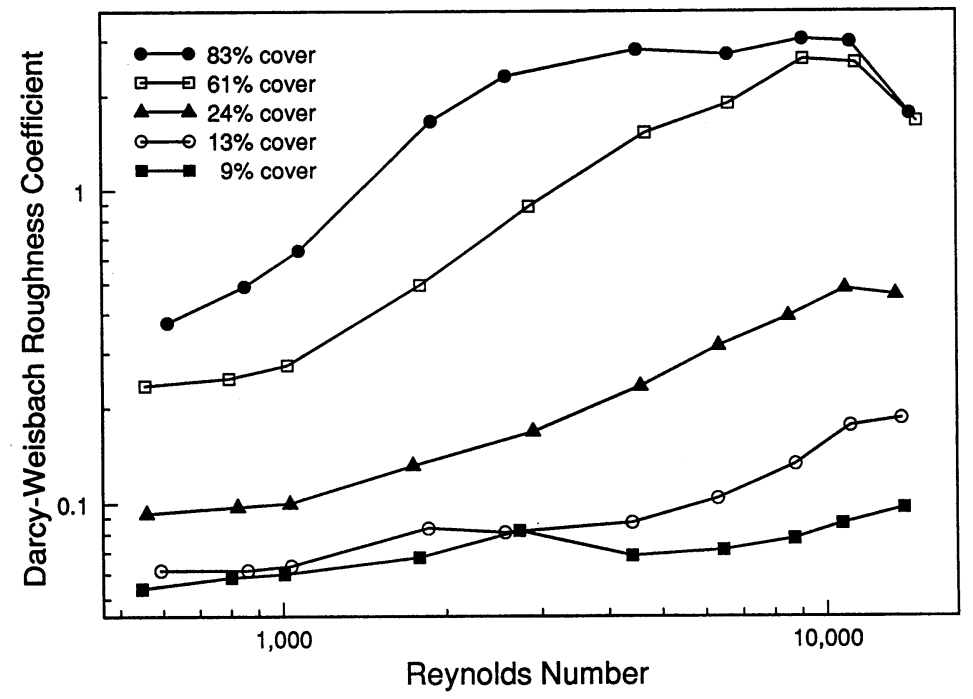

Figure 2. Darcy-Weisbach Roughness Coefficients versus Reynolds Number for Cobble Material with 12.70-25.40-cm Diameter 
Gravel or cobble diameter, percent surface cover, and flow rate were the experimental variables used in this study. Gravel or cobble materials of a given size class were glued in a random orientation onto fiberglass sheets which had been placed in a flume. Steady uniform flow conditions were then established at several discharge rates.

Flow measurements were used to calculate Darcy-Weisbach roughness coefficients. Regression relationships were developed for relating roughness coefficients to percentage of surface cover and the Reynolds number. The regression equations can be used for values of the Reynolds number from 500 to 16,000 .

Total hydraulic resistance on upland areas may be caused by several factors. Information is needed on roughness coefficients provided by each of these factors, their contribution to total hydraulic roughness, and the effect of flow rate on roughness coefficients. Our ability to understand and accurately model upland flow hydraulics will improve as this information becomes available.

\section{ACKNOWLEDGMENTS}

This paper is a contribution from the U.S. Department of Agriculture-Agricultural Research Service, Lincoln, Nebraska, in cooperation with the Agricultural Research Division, University of Nebraska, also in Lincoln.

\section{REFERENCES}

Engman, E. T. (1986). "Roughness coefficients for routing surface runoff." J. Irrig. and Drain. Engrg., ASCE, 112(1), 39-53.

Gilley, J. E., Kottwitz, E. R., and Simanton, J. R. (1990). "Hydraulic characteristics of rills." Trans. American Society of Agricultural Engineers, 33(6), 1900-1906.

Gilley, J. E., Kottwitz, E. R., and Wieman, G. A. (1991). "Roughness coefficients for selected residue materials." J. Irrig. and Drain. Engra., ASCE, 117(4), 503-514.

Laflen, J. M., Baker, J. L., Hartwig, R. O., Buchele, W. F., and Johnson, H. P. (1978). "Soil and water loss from conservation tillage systems." Trans., American Society of Agricultural Engineers, 21(5), 881-885. 